\title{
Performed Medical Condition Result Medical History Indicator
}

National Cancer Institute

\section{Source}

National Cancer Institute. Performed Medical Condition Result Medical History Indicator. NCl Thesaurus. Code C95368.

An indication as to whether the medical condition of the subject is part of that subject's medical history and therefore out of temporal bounds of the study. 